\title{
Regulation of pro-inflammatory responses by lipoxygenases via intracellular reactive oxygen species in vitro and in vivo
}

\author{
So Yong Kim ${ }^{1}$, Tae-Bum Kim², Keun-ai Moon², \\ Tae Jin Kim ${ }^{1}$, Dongwoo Shin ${ }^{1}$, You Sook $\mathrm{Cho}^{2}$, \\ Hee-Bom Moon ${ }^{2}$ and Ki-Young Lee ${ }^{1,3}$ \\ ${ }^{1}$ Department of Molecular Cell Biology \\ Samsung Biomedical Research Institute \\ Sungkyunkwan University School of Medicine \\ Suwon 440-746, Korea \\ ${ }^{2}$ Division of Allergy \\ University of Ulsan College of Medicine \\ Seoul 138-736, Korea \\ ${ }^{3}$ Corresponding author: Tel, 82-31-299-6225; \\ Fax, 82-31-299-6229; E-mail, thylee@med.skku.ac.kr \\ DOI 10.3858/emm.2008.40.4.461
}

Accepted 7 May 2008

Abbreviations: 5-LOX, 5-lipoxygenase; AHR, airway hyperresponsiveness; BAL, bronchoalveolar lavage; DCFH, 2',7'-dichlorodihydrofluorescein; EMSA, electrophoretic mobility shift assay; LTs, leukotrienes; MIF, macrophage migration inhibitory factor; NDGA, nordihydroguaiaretic acid; NOX, NADPH oxidase; OVA, ovalbumin; ROS, reactive oxygen species

\begin{abstract}
Reactive oxygen species (ROS) performs a pivotal function as a signaling mediator in receptor-mediated signaling. However, the sources of ROS in this signaling have yet to be determined, but may include lipoxygenases (LOXs) and NADPH oxidase. The stimulation of lymphoid cells with TNF- $\alpha$, IL- $1 \beta$, and LPS resulted in significant ROS production and NF-KB activation. Intriguingly, these responses were markedly abolished via treatment with the LOXs inhibitor nordihydroguaiaretic acid (NDGA). We further examined in vivo anti-inflammatory effects of NDGA in allergic airway inflammation. Both intraperitoneal and intravenous NDGA administration attenuated ovalbumin (OVA)-induced influx into the lungs of total leukocytes, as well as IL-4, IL-5, IL-13, and TNF- $\alpha$ levels. NDGA also significantly reduced serum levels of OVA-specific IgE and suppressed OVA-induced airway hyperresponsiveness to inhaled methacholine. The results of our histological studies and flow cytometric analyses showed that NDGA inhibits OVA-induced lung inflammation and the infiltration of $\mathrm{CD}_{11 \mathrm{~b}^{+}}$
\end{abstract}

macrophages into the lung. Collectively, our findings indicate that LOXs performs an essential function in pro-inflammatory signaling via the regulation of ROS regulation, and also that the inhibition of LOXs activity may have therapeutic potential with regard to the treatment of allergic airway inflammation.

Keywords: anti-inflammatory agents; asthma; lipoxygenase; macrophages; models, animal; NF- $\mathrm{B}$; reactive oxygen species

\section{Introduction}

The physiological balance of reactive oxygen species (ROS) is ultimately determined by the rate of $\mathrm{O}_{2}^{-}$production, the metabolism rate of $\mathrm{O}_{2}^{-}$by endogenous superoxide dismutases (SODs), and the removal rate of $\mathrm{H}_{2} \mathrm{O}_{2}$ via antioxidant enzymes (catalase or glutathione peroxidase) and/or involvement in Haber-Weiss or Fenton chemistry (Adler et al., 1999; Haddad et al., 2002; Miller et al., 2006). In mammalian cells, potential enzymatic $\mathrm{O}_{2}{ }^{-}$sources include the mitochondrial electron-transport chain, the arachidonic acid-metabolizing enzymes (cyclooxygenase and lipoxygenase), the cytochrome P450s, xanthine oxidase, NADPH-oxidases, and NO synthases (Babior et al., 1999; Griendling et al., 1999; Van Heerebeek et al., 2002; Ogawa et al., 2003; Genova et al., 2004). Among these, the NADPH-oxidases (NOX) and cyclooxygenases / lipoxygenases are generally recognized as the principal physiological sources of $\mathrm{O}_{2}^{-}$, which is in turn dismutated into $\mathrm{H}_{2} \mathrm{O}_{2}$ (Babior et al., 1999; Griendling et al., 1999; Van Heerebeek et al., 2002; Kuhn et al., 1999; Rhee et al., 2003). $\mathrm{H}_{2} \mathrm{O}_{2}$ is now generally believed to be one of the most important ROS molecules in the modulation of multiple cellular events, including receptor-mediated signaling, apoptosis, proinflammation, and metabolism (Davies et al., 1999; Lee et al., 1999; Aslan et al., 2003; Tonks et al., 2005; Saito et al., 2006). Although the sources of ROS generated after stimulation with proinflammatory cytokines such as TNF- $\alpha$ and IL-1 $\beta$ remain to be clearly elucidated, several reports have indicated that 5-lipoxygenase (5-LOX) activity may be critically related to intracellular ROS production (Los et al., 1995; Lee et al., 1997). The 5-LOX enzyme catalyzes the 
production of leukotrienes and ROS from arachidonic acid (Lewis et al., 1990; Harrison et al., 1995). During in vivo inflammatory responses, the leukotrienes (LTs) B4, C4, D4, and E4 generated by the 5-LOX pathway of arachidonic acid metabolism have been experimentally determined to perform a function in each of these inflammatory mechanisms (Samuelsson et al., 1983; O'Byrne et al., 1997). Clinical and experimental studies have shown that selective $\mathrm{LTD}_{4}$ receptor antagonists, including pranlukast, zafirlukast, MK-571, and MK-679 have potential effects with regard not only to the amelioration of asthma symptoms, but also in terms of the use of $\beta$ 2-agonists and bronchoconstriction induced by exposure to allergens, exercise, aspirin, and cold air (Samuelsson et al., 1983; O'Byrne et al., 1997; Gaddi et al., 2004; Leone et al., 2007).

Asthma is a chronic airway disease characterized by eosinophilic inflammation and airway hyperresponsiveness (AHR) (Akdis et al., 2006; Eder et al., 2006; Umetsu et al., 2006). Increased ROS generation, which results in an imbalance between oxidative forces and the antioxidant defense systems, has been implicated in the pathogenesis of asthma (Rahman et al., 1999; Dworski et al., 2000; Rahman et al., 2000; Lee et al., 2006, 2007; Kirkham et al., 2006). ROS are capable of eliciting a variety of pathological changes, including the peroxidation of lipids, proteins, and DNA and the generation of chemoattractants, as well as enhancements of AHR, airway secretion, and vascular permeability in asthmatic airways (Barnes et al., 1990; Henricks et al., 2001; Andreadis et al., 2003). These changes ultimately result in increased mediator release from the epithelium, which leads to the recruitment of immune effector cells. Inflammatory cells such as macrophages, lymphocytes, mast cells, B cells, and eosinophils have been proposed to perform critical functions in the initiation, development, and chronicity of this disease (Williams et al., 2000; Elias et al., 2003; Akdis et al., 2006; Eder et al., 2006; Umetsu et al., 2006). These inflammatory cells contribute to the generation of Th2 cytokines (IL-4, IL-5, and IL-13), chemokines (eotaxin and RANTES), and TNF- $\alpha$, which are detected at elevated levels in asthmatic lungs (Williams et al., 2000; Elias et al., 2003). Therefore, the regulation of intracellular ROS during inflammation may have potential advantages with regard to the treatment of inflammatory diseases.

In this study, we have attempted to determine the roles of lipoxygenases (LOXs) in both proinflammatory signaling in vitro and allergic airway inflammation in vivo. To that end, we utilized Nordihydroguaiaretic acid (NDGA), LOXs inhibitor. The results of previous studies have shown that NDGA exerts pleiotropic effects capable of influencing a broad variety of cellular processes, including growth factor-and TNF-induced signal transduction, leukocyte chemotaxis, myoblast cell differentiation, cancer cell proliferation, and viral proliferation in infected cells (Goetzl et al., 1980; Gnabre et al., 1995; Lee et al., 2003; West et al., 2004; Ito et al., 2005; Youngren et al., 2005; Arasaki et al., 2007). It can also induce the expression of NOS, regulate calcium channel activity, and inhibit the growth of $\beta$-amyloid protofibrils (Ramasamy et al., 1999; Huang et al., 2004; Moss et al., 2004). Although many of the effects of NDGA on cellular events appear to be attributable to its function as LOXs inhibitor, the more detailed mechanism by which NDGA interferes as an antioxidant with the proinflammatory signaling pathway has yet to be clearly elucidated. Moreover, its therapeutic effects on allergic inflammation had not, prior to this study, been evaluated. Our findings indicate a specific role of LOXs in proinflammatory signaling via the regulation of ROS, and also point to the potential therapeutic utility inherent to the inhibition of LOXs activity in the treatment of allergic airway inflammation.

\section{Materials and Methods}

\section{Intracellular 2',7'-dichlorodihydrofluorescein staining}

The oxidation of $2^{\prime}, 7^{\prime}$-dichlorodihydrofluorescein (DCFH) to fluorescent 2',7'-dichlorofluorescein (DCF) was evaluated in order to determine the intracellular levels of $\mathrm{H}_{2} \mathrm{O}_{2}$. RAW 264.7 (Mouse macrophage cell line), Jurkat (Human T lymphoma cell line), THP-1 (human acute monocytic leukemia cell line), and BEAS 2B (Human bronchial epithelial cell line) cells were pre-treated with $5 \mu \mathrm{M}$ NDGA (Plymouth Meeting, PA) or REV5901 for different times, as indicated in each experiment, in an atmosphere of $5 \% \mathrm{CO}_{2}$ at $37^{\circ} \mathrm{C}$. In addition, the scavenger activity of REV5901 (Calbiochem, San Diego, CA) was evaluated in RAW 264.7 cells, following the protocol above. As an independent experiment, Jurkat cells were pre-treated with 5 $\mu \mathrm{M}$ NDGA for different times (30 min, $45 \mathrm{~min}$, and $60 \mathrm{~min}$ ), then stimulated for $1 \mathrm{~h}$ with $1 \mathrm{ng} / \mathrm{ml}$

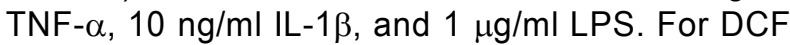
staining, DCFH was added at a final concentration of $20 \mu \mathrm{M}$ and incubated for $30 \mathrm{~min}$ at $37^{\circ} \mathrm{C}$. The cells were washed once in phosphate-buffered saline (PBS) and maintained in $1 \mathrm{ml}$ of medium. Cellular fluorescence was determined via flow cytometry (FACSCalibur Becton- Dickinson, Franklin 
Lakes, NJ). Measurements were conducted at $510-540 \mathrm{~nm}$ after the excitation of cells at $488 \mathrm{~nm}$ using an argon ion laser.

\section{Confocal microscopy}

For confocal microscopy analysis, the RAW 264.7 cells were grown on $0.2 \%$ gelatin-coated coverslips, pre-treated for $1 \mathrm{~h}$ with or without $5 \mu \mathrm{M}$ NDGA, then stimulated for $1 \mathrm{~h}$ with $1 \mathrm{ng} / \mathrm{ml}$ TNF- $\alpha, 10$

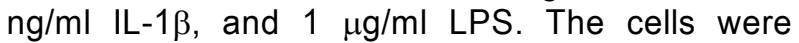
washed in PBS, fixed for 30 min with $4 \%$ paraformaldehyde at room temperature, and permeabilized with permeabilization buffer $(0.05 \%$ saponin, $1 \%$ FBS, $10 \mathrm{mM}$ Hepes, and $10 \mathrm{mM}$ glycine in PBS, $\mathrm{pH} 7.5)$ for $30 \mathrm{~min}$ at room temperature. The cells were incubated with anti-5-LOX antibody (Santa Cruz Biotechnology, Santa Cruz, CA) for 30 min at room temperature, then incubated with goat antirabbit antibody conjugated with FITC. The cells were subsequently washed three times with PBS, mounted with GEL/MOUNT (Biomeda, Foster City, $\mathrm{CA}$ ), and examined under an Olympus Fluoview 300 Confocal Laser Scanning head with an Olympus IX70 inverted microscope.

\section{Luciferase reporter assay}

RAW 264.7 cells $\left(4 \times 10^{5}\right)$ grown on 12 -well plates were transiently transfected with the NF-кBdependent reporter construct, pBllx-luc, coupled with the Renilla luciferase vector, using FuGENE 6 (Roche Diagnostics Corg., Indianapolis, IN). The total DNA concentration in each of the experiments was maintained via the addition of the appropriate empty vector to the DNA mixture. $48 \mathrm{~h}$ after transfection, the cells were treated for $6 \mathrm{~h}$ with $1 \mu \mathrm{g} / \mathrm{ml}$ of LPS and $1 \mathrm{ng} / \mathrm{ml}$ of TNF- $\alpha$, after $1 \mathrm{~h}$ of pre-treatment with different concentrations of NDGA $(1 \mu \mathrm{M}, 5 \mu \mathrm{M}$, and $10 \mu \mathrm{M})$. The cells were lysed, and the luciferase activity was determined using a dual luciferase assay kit (Promega Corp., Madison, WI). The $\kappa \mathrm{B}$-specific luciferase activity was normalized on the basis of the renilla luciferase control.

\section{Electrophoretic mobility shift assay (EMSA)}

RAW 264.7 cells were plated at a density of $5 \times$ $10^{6}$ cells for $24 \mathrm{~h}$ in 6 -well plates. The cells were then treated for $1 \mathrm{~h}$ with different concentrations of NDGA, and stimulated for $3 \mathrm{~h}$ with $1 \mu \mathrm{g} / \mathrm{ml}$ of LPS or $1 \mathrm{ng} / \mathrm{ml}$ of TNF- $\alpha$. The nuclear extracts were prepared using a specific extraction kit (Sigma, St. Louis, MO). NF- $\kappa$ B activation was evaluated using consensus oligonucleotides of the transcription factor. The consensus sequence was AGTTGAGGGGACTTTCCCAGGC. The probes were endlabeled with T4 polynucleotide kinase in the presence of $\left[\gamma^{32} \mathrm{P}\right]$ ATP, and purified on a Nick column (Amersham Biosciences, Little Chalfont, UK). Nuclear protein $(5 \mu \mathrm{g})$ was incubated for $20 \mathrm{~min}$ with labeled probes at room temperature. The mixture was separated via $6 \%$ SDS- PAGE, and the resultant gel was dried and subjected to autoradiography.

\section{Measurement of TNF- $\alpha$ production}

RAW 264.7 cells were plated onto 24-well tissue culture plates. The cells $\left(1 \times 10^{6}\right.$ cells $\left./ \mathrm{ml}\right)$ were then treated for $1 \mathrm{~h}$ with different concentrations of NDGA $(1 \mu \mathrm{M}, 5 \mu \mathrm{M}$, and $10 \mu \mathrm{M})$, and stimulated for $5 \mathrm{~h}$ with $1 \mu \mathrm{g} / \mathrm{ml}$ LPS. The quantity of TNF- $\alpha$ in the culture supernatant fractions was determined using an ELISA kit, in accordance with the manufacturer's instructions (R\&D Systems Inc., Minneapolis, MN). The concentration of TNF- $\alpha$ in each sample was calculated from a standard curve which was prepared using known quantities of recombinant TNF- $\alpha$.

\section{A protocol for the animal model of asthma}

Six-week-old male BALB/c mice were maintained in a specific, pathogen-free area and were provided with OVA-free feed and water. Mice were sensitized on days 1 and 14 via intraperitoneal injection of $20 \mu \mathrm{g}$ OVA emulsified in $1 \mathrm{mg} \mathrm{Al}(\mathrm{OH})_{3}$ (alum), followed by an identical booster injection administered on day 14 . On days 21,22 , and 23 after initial sensitization, the mice were challenged for $30 \mathrm{~min}$ with an aerosol of $5 \%$ OVA (wt/vol in PBS) using an ultrasonic nebulizer. For the inhalation challenge, the mice were placed in a $30 \times 30 \times$ $15 \mathrm{~cm}$ plastic chamber with small ventilation holes on one side, and the OVA solution was aerosolized using an ultrasonic nebulizer that was attached directly to the chamber opposite the ventilation holes. NDGA (10 mg/kg and $20 \mathrm{mg} / \mathrm{kg}$ ) or vehicle control $(0.05 \% \mathrm{DMSO})$ diluted with $0.9 \% \mathrm{NaCl}$ was administered in a volume of $50 \mu$ l either intraperitoneally or intravenously to each animal on days 21 , 22 , and 23. All experiments described herein were approved by the Animal Research Ethical Review Board of the Asan Institute for Life Sciences.

\section{Determination of AHR}

$24 \mathrm{~h}$ after the final aerosol challenge, AHR was evaluated in conscious, unrestrained mice via whole-body plethysmography. Each mouse was 
placed in a plastic chamber and exposed to aerosolized normal saline, followed by increasing concentrations of aerosolized methacholine solutions $(2.5,5,10$, and $20 \mathrm{mg} / \mathrm{ml}$; Sigma) for $3 \mathrm{~min}$. Beginning $10 \mathrm{~s}$ after each aerosol exposure and lasting for $3 \mathrm{~min}$, enhanced pause (Penh) readings, calculated automatically on the basis of the mean pressure generated within the plethysmography chamber during inspiration and expiration combined with the time of each phase, were recorded and averaged. The values were expressed as the percentage change in Penh at each methacholine concentration, as compared with the baseline readings.

\section{Collection of serum and BAL samples}

$24 \mathrm{~h}$ after the last challenge, the mice were sacrificed via overdose of pentobarbital-Na (100 $\mathrm{mg} / \mathrm{kg}$ of body weight, administered via intraperitoneal injection). Blood was drawn via puncture of the vena cava, then centrifuged. Serum was shock-frozen in liquid nitrogen and stored at $-70^{\circ} \mathrm{C}$ for measurements of $\mathrm{lgE}$. In order to collect bronchoalveolar lavage (BAL) fluids, the chest cavity was exposed to allow for expansion, after which the trachea was carefully intubated, and the catheter was secured with ligatures. Pre-warmed, $0.9 \%$ $\mathrm{NaCl}$ solution was then slowly infused into the lungs and withdrawn. The total BAL cells were counted with a hemocytometer. Differential cell counts were acquired from BAL cells spun down onto slides using a cytocentrifuge (Shannon Scientific Ltd., Cheshire, UK) and treated with Diff-Quik solution (Dade Diagnostics of Puerto Rico Inc., Aguada, Puerto Rico). Two independent, blinded investigators counted the cells with a microscope. Approximately 400 cells in each of four different random locations were counted by two independent, blinded investigators. The inter-investigator variation was $<7 \%$. The mean number obtained from the reports of the two investigators was used to estimate the cell differentials.

\section{Histologic assay}

$24 \mathrm{~h}$ after the final challenge, the mice were sacrificed and the lungs were removed and fixed with $10 \%$ (vol/vol) neutral-buffered formalin. The specimens were dehydrated and embedded in paraffin. For the histologic examination, $4 \mu \mathrm{m}$ sections of fixed, embedded tissues were cut on a Leica (model 2165) rotary microtome (Leica Microsystems Nussloch $\mathrm{GmbH}$, Nussloch, Germany), placed on glass slides, de-paraffinized, and stained with hematoxylin 2, eosin-Y (Richard-Allan Scientific,
Kalamazoo, MI).

\section{Measurement of BAL cytokines and the ELISPOT assay}

Levels of IL-4, IL-5, IL-13, and TNF- $\alpha$ were quantified in the supernatants of the BAL fluids via enzyme immunoassays, all of which were conducted in accordance with the manufacturer's recommendations (R\&D Systems, Inc., Minneapolis, MN). For the counting of IL-4, IL-5, IL-13, and TNF- $\alpha$ producing cells, ELISPOT assay kits (R\&D Systems, Inc.) were used, again in accordance with the manufacturer's instructions. $1.6 \times 10^{5}$ splenocytes were tested in a volume of $100 \mu$ l. The cells were stimulated with PMA (20 ng/ml; Sigma) and ionomycin ( $1 \mu \mathrm{M}$; Sigma) for $12 \mathrm{~h}$ at $37^{\circ} \mathrm{C}$ in a humidified atmosphere containing $5 \% \quad \mathrm{CO}_{2}$. The spots were counted using Elispot leader 4.0 (AIDGmbH, Strassberg, Germany). Unstimulated cells were used as a negative control. No spots were detected in the control wells.

\section{Flow cytometric analysis}

Lung tissue was cut into small fragments, and washed thoroughly in RPMI culture medium. Each tissue sample was incubated for $1 \mathrm{~h}$ in RPMI containing $0.1 \%$ collagenase (Type IV; Sigma), $0.01 \%$ hyaluronidase (Sigma), and $0.002 \%$ DNase (Sigma). The samples were incubated for $1 \mathrm{~h}$ in RPMI containing $0.1 \%$ collagenase (Type IV; Sigma), $0.01 \%$ hyaluronidase (Sigma), and $0.002 \%$ DNase (Sigma). Cells were washed in medium containing $10 \%$ FBS. Viable cells were isolated via Ficollhypaque (Sigma) density centrifugation, and washed twice in RPMI medium without serum. The cells were incubated for $40 \mathrm{~min}$ on ice with FITC-conjugated anti-CD11b (M1/70) (BD PharMingen, San Diego, CA). The cells were washed three times in PBS buffer, and analyzed using FACScalibur apparatus (Becton-Dickinson).

\section{Measurement of BAL leukotriene $\mathrm{C}_{4}$}

Levels of $\mathrm{LTC}_{4}$ were quantified in the supernatants of the BAL fluids via enzyme immunoassay, conducted in accordance with the manufacturer's protocols (Cayman Chemical Co., Ann Arbor, MI). The lower detection limit for $\mathrm{LTC}_{4}$ in this assay was $10 \mathrm{pg} / \mathrm{ml}$.

\section{Statistical analysis}

All data are expressed as the mean \pm SEM. For comparison between groups, the Mann-Whitney 
and Kruskal-Wallis tests were used. Statistical significance was defined as $P<0.05$.

\section{Results}

\section{NDGA, LOXs inhibitor, evidences strong antioxidant activity in lymphoid cells}

We first attempted to determine whether NDGA, LOXs inhibitor, manifests scavenger activity via the inhibition of LOXs in lymphoid cells. Raw 264.7 (Mouse macrophage cell line), THP1 (Human acute monocytic leukemia cell line), Jurkat (Human T lymphoma cell line), BEAS 2B (Human bronchial epithelial cell) cells were treated with $5 \mu \mathrm{M}$ NDGA, and its scavenger activity was analyzed using DCFH probes (Chang et al., 2004). The NDGA treatments induced significant reductions in intracellular ROS in the tested cell lines, and these reductions occurred in a time-dependent manner (Figure 1A, Raw cells; Figure 1B, THP1 cells; Figure 1C, Jurkat cells; Figure 1D, BEAS 2B cells). With regard to mean fluorescence intensity, the elimination of ROS by NDGA occurred quickly and reached a plateau 30 min after the administration of NDGA treatment, as depicted in the left panels (Figure 1). Following treatment of REV5901, 5-LOX inhibitor, the significant reduction of intracellular
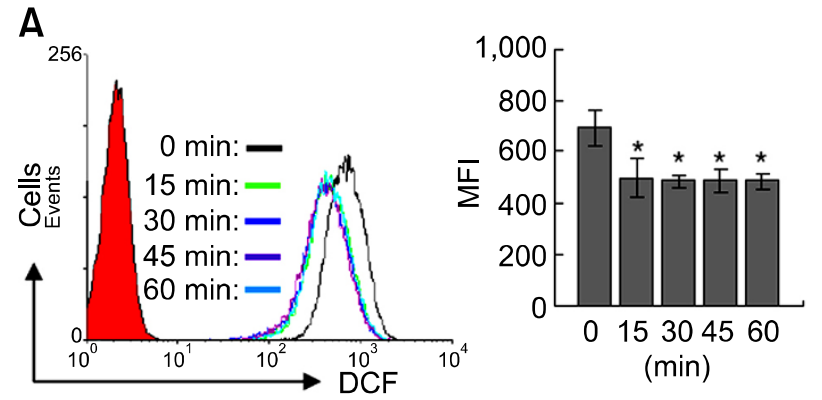

B
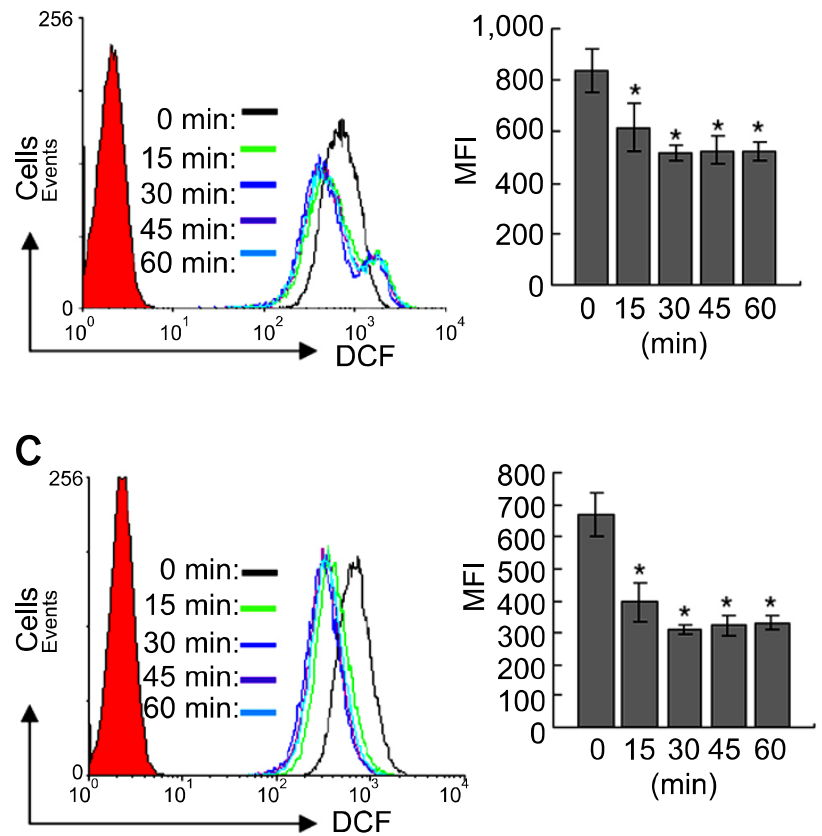
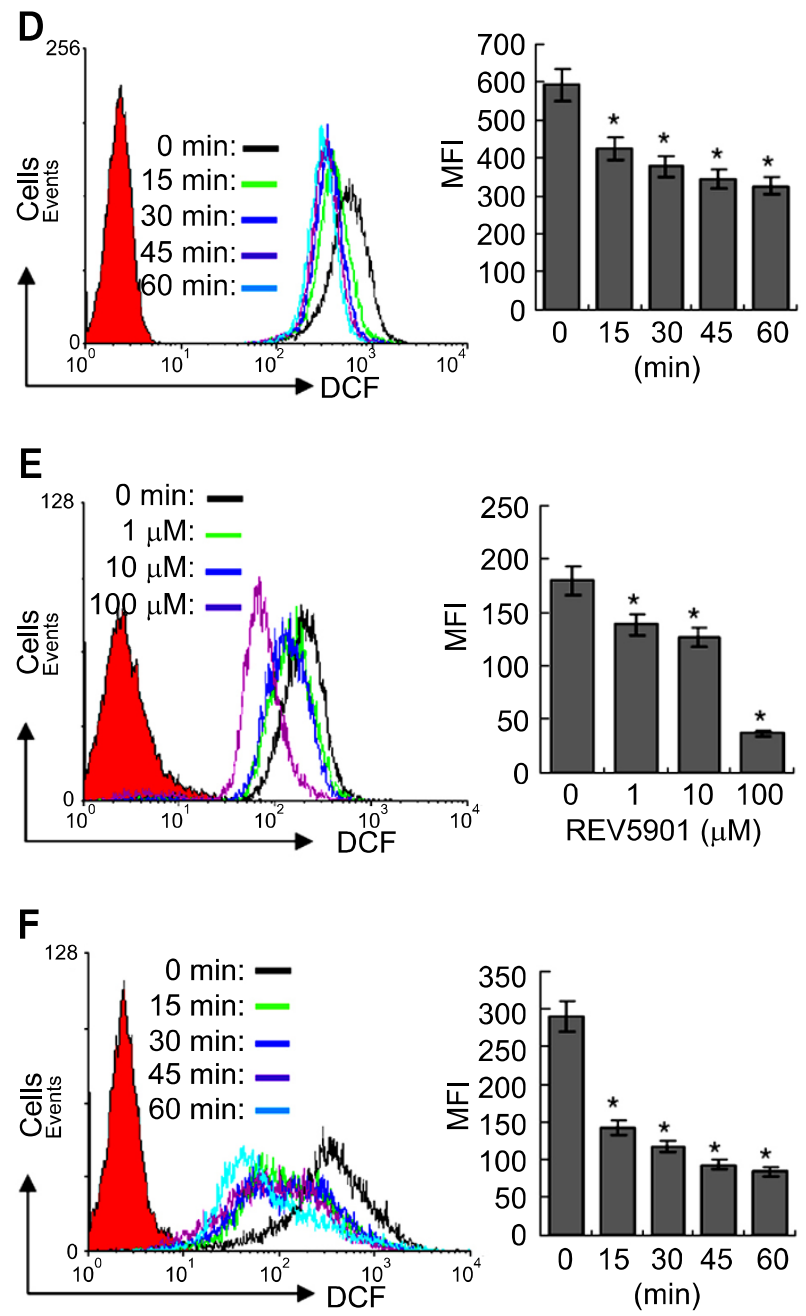

Figure 1. Scavenger activity of NDGA, LOXs inhibitor, in lymphoid cells. Raw 264.7 cells, THP-1 cells, Jurkat cells, BEAS 2B cells were treated with or without $5 \mu \mathrm{M}$ NDGA for different times, as indicated. The cells were treated with $20 \mu \mathrm{M} \mathrm{DCFH}$ and incubated for $30 \mathrm{~min}$ at $37^{\circ} \mathrm{C}$. The levels of ROS were determined via flow cytometry (A, RAW 264.7 cells; B, THP-1 cells; C, Jurkat cells; D, BEAS 2B cells). Raw 264.7 cells were treated with different concen-

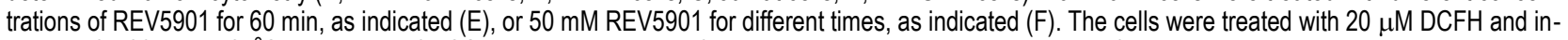
cubated for $30 \mathrm{~min}$ at $37^{\circ} \mathrm{C}$. The levels of ROS were determined via flow cytometry. Data are representative of three individual experiments. Decreases in mean fluorescence intensity were represented in the right panels. The bar represents the mean \pm SE from three individual experiments. ${ }^{\star} P<0.05$ vs control (0 min). 
ROS could be detected with both a dosedependent and a time-dependent manner in Raw 264.7 cells (Figure $1 \mathrm{E}$ and $\mathrm{F}$ ). The results show that LOXs is essential for the generation of intracellular ROS in lymphoid cells. This observation is, in part, consistent with the results of previous reports (Los et al., 1995; Lee et al., 1997).

\section{LOXs are essential for the production of intracellular ROS by pro-inflammatory stimuli such as TNF- $\alpha$, IL-1 $\beta$, and LPS}

We next attempted to determine whether pro-inflammatory stimuli including TNF- $\alpha, \mathrm{IL}-1 \beta$, and LPS can affect intracellular ROS levels. Jurkat cells were stimulated for $1 \mathrm{~h}$ with TNF- $\alpha$, IL-1 $\beta$, and LPS, and then ROS levels were evaluated using DCF dye. The levels of ROS were increased significantly after stimulation with TNF- $\alpha$ (Figure $2 \mathrm{~A}$, blue line), IL-1 $\beta$ (Figure 2B, blue line), and LPS (Figure 2C, blue line). Intriguingly, when the cells were pre-treated with NDGA to inhibit LOXs activity, these stimuli were incapable of enhancing intracellular ROS levels; rather, ROS levels were markedly reduced, as is shown in Figure $2 \mathrm{~A}$, Figure 2B, and Figure 2C (purple lines). The results indicate that LOXs may prove to be essential for the generation of intracellular ROS by proinflammatory stimuli, including TNF- $\alpha, \mathrm{IL}-1 \beta$, and LPS. It is generally accepted that, upon stimulation,
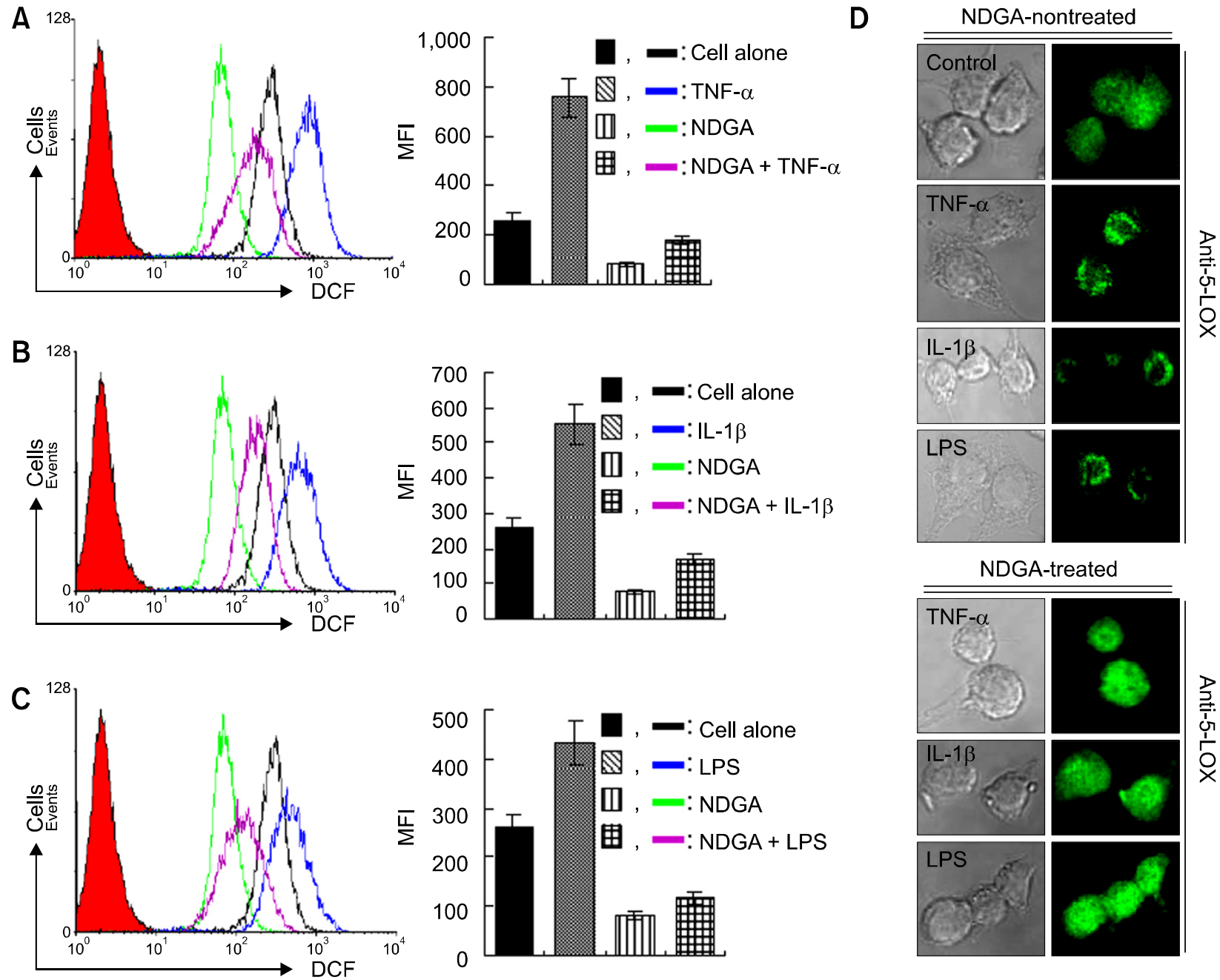

Figure 2. NDGA inhibits TNF- $\alpha$, IL-1 $\beta$, and LPS-induced ROS production and translocation of 5-LOX into the nuclear membrane. Jurkat cells were treated for $1 \mathrm{~h}$ with or without $5 \mu \mathrm{M} \mathrm{NDGA}$ and stimulated for $1 \mathrm{~h}$ with $1 \mathrm{ng} / \mathrm{ml} \mathrm{TNF}-\alpha, 10 \mathrm{ng} / \mathrm{ml} \mathrm{IL-} 1 \beta$, and $1 \mu \mathrm{g} / \mathrm{ml}$ LPS for $1 \mathrm{~h}$. For DCF staining, DCFH was added at a final concentration of $20 \mu \mathrm{M}$ and incubated for $30 \mathrm{~min}$ at $37^{\circ} \mathrm{C}$. ROS levels were analyzed via flow cytometry (A, TNF- $\alpha$; B, IL-1 $\beta$; C, LPS) Data are representative of three individual experiments. Decreases in mean fluorescence intensity were represented in the right panels. (D) Raw264.7 cells were treated for $1 \mathrm{~h}$ with or without $5 \mu \mathrm{M}$ NDGA and stimulated for $1 \mathrm{~h}$ with $1 \mathrm{ng} / \mathrm{ml} \mathrm{TNF}-\alpha, 10 \mathrm{ng} / \mathrm{ml} \mathrm{IL}-1 \beta$, and $1 \mu \mathrm{g} / \mathrm{ml}$ LPS. The localization of 5 -LOX was analyzed via confocal microscopy, as described in the Materials and Methods section. 
intranuclear or intracellular 5-LOX binds to the nuclear membrane for the activation of 5-LOX (Healy et al., 1999). Interestingly, TNF- $\alpha, I L-1 \beta$, and LPS stimulation induced a significant translocation of 5-LOX into the nuclear membrane (Figure 2D, upper panels). However, NDGA pre-treatment markedly inhibited the localization of 5-LOX as a result of these stimuli (Figure 2D, down panels). These results strongly indicate that LOXs including 5-LOX may essentially involve intracellular ROS production in pro-inflammatory signaling such as
A

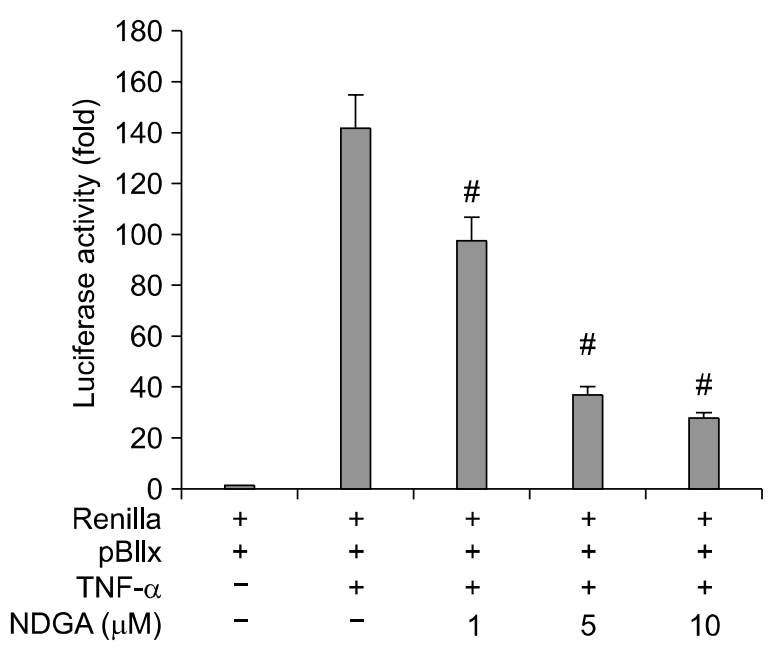

C

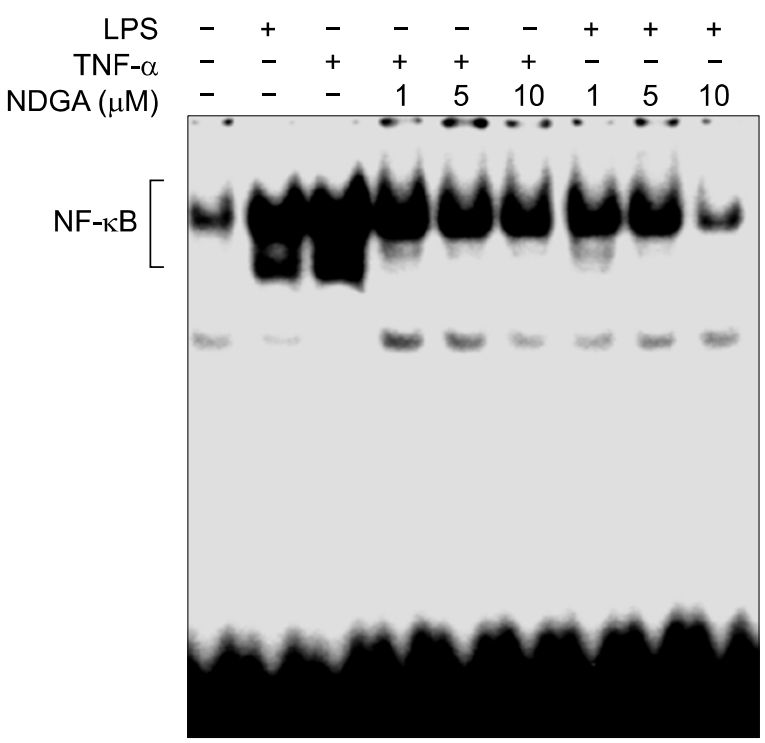

B

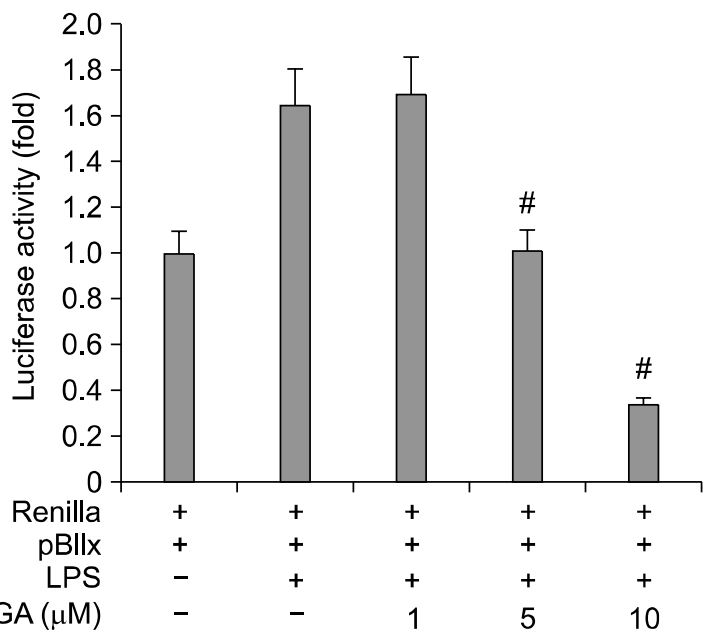

D

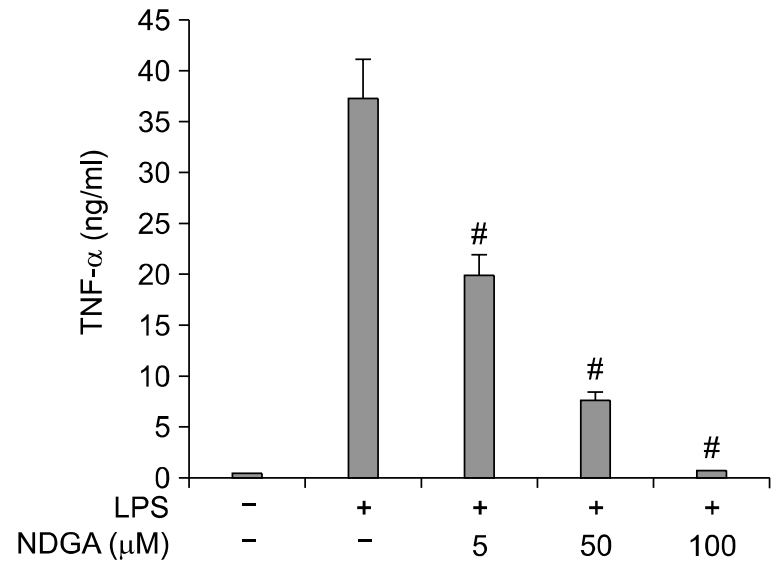

Figure 3. NDGA inhibits TNF- $\alpha$ and LPS-induced NF- $\kappa B$ activation and LPS-mediated TNF- $\alpha$ production. (A) and (B) RAW 264.7 cells transfected (in 24-well plates) with a $\kappa B$-luciferase reporter $(100 \mathrm{ng})$ and a control Renilla luciferase reporter. The cells were pre-treated with different NDGA concentrations as indicated for $1 \mathrm{~h}$, then stimulated for $5 \mathrm{~h}$ with $1 \mathrm{ng} / \mathrm{ml} \mathrm{TNF}-\alpha(\mathrm{A})$ or $1 \mu \mathrm{g} / \mathrm{ml} \mathrm{LPS}(\mathrm{B})$. The luciferase assay was conducted as described in the Materials and Methods section. NF-kB-specific luciferase activity was normalized on the basis of the Renilla luciferase control. The results are expressed as the fold induction in luciferase activity relative to that of untreated cells. Error bars indicate standard deviation. ${ }^{*} P<0.05$ vs NDGA-no-treated control. (C) Raw 264.7 cells were treated with different NDGA concentrations as indicated for $1 \mathrm{~h}$, stimulated for $5 \mathrm{~h}$ with $1 \mathrm{ng} / \mathrm{ml} \mathrm{TNF}-\alpha$ or $1 \mathrm{ng} / \mathrm{ml}$ LPS, and the nuclear extracts were prepared. NF-KB DNA-binding activity was analyzed via EMSA as described in the Materials and Methods section. (D) Raw 264.7 cells were treated with different concentrations of NDGA as indicated for $1 \mathrm{~h}$, and stimulated for $5 \mathrm{~h}$ with $1 \mu \mathrm{g} / \mathrm{ml}$ LPS. The quantity of TNF- $\alpha$ in the culture supernatant fractions was determined via ELISA, as described in the Materials and Methods section. Error bars indicate standard deviation. ${ }^{*} P<0.05$ vs NDGA-no-treated control. 
that associated with TNF- $\alpha$, IL-1 $1 \beta$, and LPS.

\section{LOXs are required for the activation of NF- $\mathrm{KB}$ in pro-inflammatory signaling}

We then attempted to determine whether or not LOXs are required for the activation of NF-KB in pro-inflammatory signaling. In order to address this question, we initially ascertained whether NDGA inhibits TNF- $\alpha$-induced NF-kB reporter activity. Raw 264.7 cells were pre-treated with different NDGA concentrations, as is indicated in Figure $3 \mathrm{~A}$, for 1 $\mathrm{h}$, and then stimulated for $5 \mathrm{~h}$ with TNF- $\alpha$. The luciferase assay showed that NDGA pretreatment resulted in a marked inhibition of TNF- $\alpha$-induced $N F-\kappa B$ reporter activity in a dose-dependent manner (Figure $3 A$ ). In parallel with those results, upon pretreatment with NDGA, NF-kB reporter
A

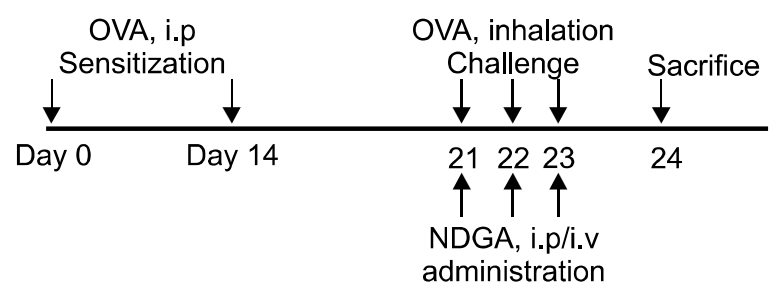

B

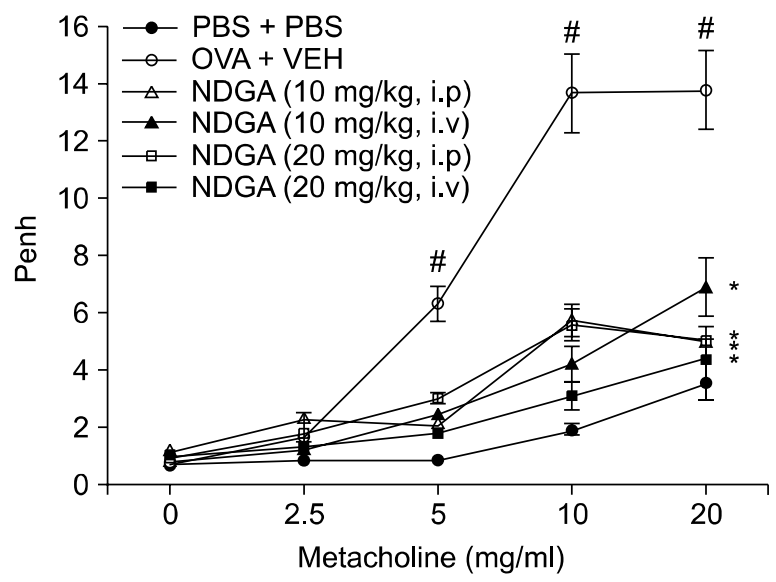

D
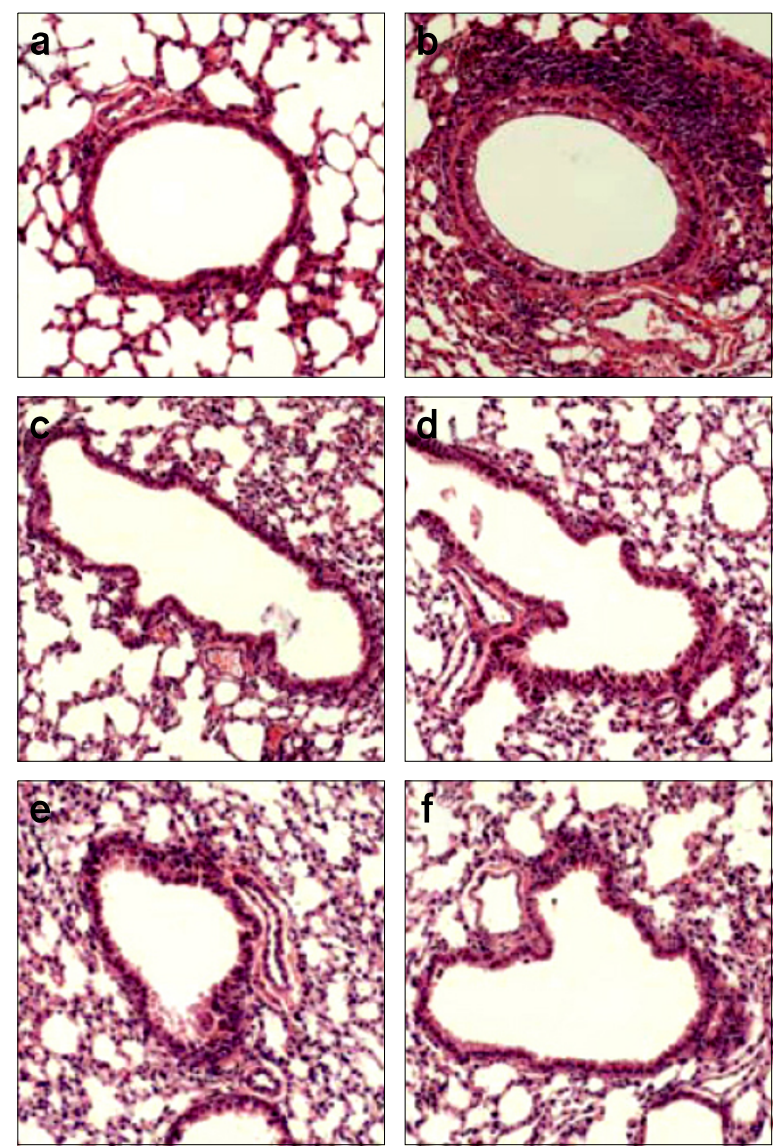

Figure 4. NDGA attenuates airway hyperresponsiveness and inflammation in a murine asthma model. (A) Six-week-old male BALB/c mice were sensitized on days 1 and 14 via intraperitoneal injection of $20 \mu \mathrm{g}$ OVA emulsified in $1 \mathrm{mg} \mathrm{Al}(\mathrm{OH})_{3}$ (alum), followed by an identical booster injection on day 14 . On days 21, 22, and 23 after initial sensitization, the mice were challenged for 30 min with an aerosol of 5\% OVA (wt/vol in PBS) using an ultrasonic nebulizer. NDGA (10 mg/kg and $20 \mathrm{mg} / \mathrm{kg}$ ) or vehicle control $(0.05 \% \mathrm{DMSO})$ diluted with $0.9 \% \mathrm{NaCl}$, was administered either intraperitoneally or intravenously in a volume of $50 \mu \mathrm{l}$ in triplicate to each animal on days 21, 22, and 23. (B) Airway hyperresponsiveness was measured $24 \mathrm{~h}$ after the last challenge in saline-inhaled mice to which PBS was administered (PBS + PBS), OVA-inhaled mice to which drug vehicle was intraperitoneally administered (OVA + VEH), OVA-inhaled mice to which $10 \mathrm{mg} / \mathrm{kg} \mathrm{NDGA}$ was intraperitoneally administered (NDGA $10 \mathrm{mg} / \mathrm{kg}$ i.p), OVA-inhaled mice to which $10 \mathrm{mg} / \mathrm{kg}$ NDGA was intravenously administered (NDGA $10 \mathrm{mg} / \mathrm{kg}$ i.v), OVA-inhaled mice to which $20 \mathrm{mg} / \mathrm{kg}$ NDGA was intraperitoneally administered (NDGA 20 $\mathrm{mg} / \mathrm{kg}$ i.p), and OVA-inhaled mice to which $20 \mathrm{mg} / \mathrm{kg} \mathrm{NDGA}$ were intravenously administered (NDGA $20 \mathrm{mg} / \mathrm{kg}$ i.v), as described in the Materials and Methods. Data represent mean \pm SE from 6 independent experiments. ${ }^{\sharp} P<0.05$ vs PBS+PBS mice and ${ }^{*} P<0.05$ vs OVA + VEH mice. (C) The number of total cells and differential cellular component of BAL fluids from each of the mice described above were counted $24 \mathrm{~h}$ after the last challenge. Differential cell counts were conducted on a minimum of 400 cells in each of four different random locations to identify macrophages (Mac), eosinophils (Eos), neutrophils (Neu), and lymphocyte (LyM). Bars represent mean \pm SE from 6 independent experiments. ${ }^{\#} P<0.05$ vs PBS + PBS mice and ${ }^{*} P<$ 0.05 vs OVA + VEH mice. (D) Lung tissue was fixed, sectioned to a thickness of $4 \mu \mathrm{M}$ and stained as described in the Materials and Methods section (a, PBS + PBS; b, OVA + VEH, c, NDGA $10 \mathrm{mg} / \mathrm{kg}$ i.p; d, NDGA $10 \mathrm{mg} / \mathrm{kg}$ i.v; e, NDGA $20 \mathrm{mg} / \mathrm{kg}$ i.p; f, NDGA $20 \mathrm{mg} / \mathrm{kg}$ i.v). (E) Mouse serum samples were collected $24 \mathrm{~h}$ after the last challenge. The levels of OVA-specific lgE were analyzed using ELISA. Bars represent mean \pm SE from 6 independent experiments. ${ }^{*} P<0.05$ vs OVA + VEH mice. 
C

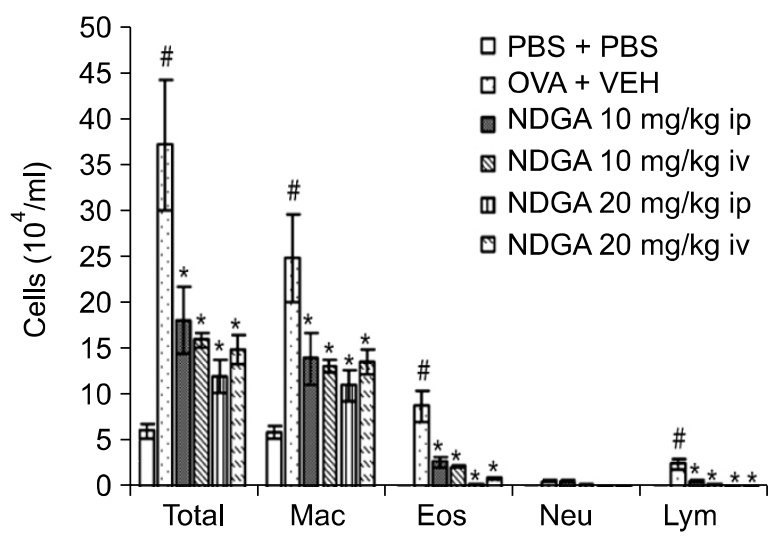

E

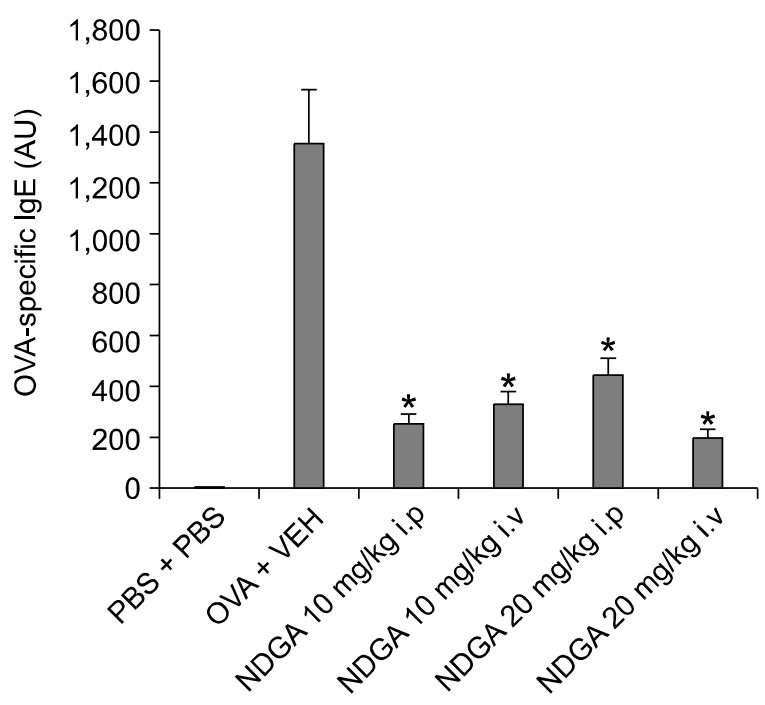

Figure 4. Continued.

activity after LPS stimulation was inhibited significantly (Figure 3B). In the electrophoretic gel mobility shift (EMSA) assay, moreover, NF-KB DNA-binding activities were substantially reduced in NDGA-pre-treated Raw cells, followed by TNF- $\alpha$ and LPS stimulation (Figure 3C). Moreover, NDGA markedly attenuated LPS stimulation-induced TNF- $\alpha$ production (Figure 3D). Collectively, these results strongly indicate that LOXs are required for the activation of NF- $\mathrm{NB}$ in pro-inflammatory signaling, such as that associated with TNF- $\alpha$ and LPS.

\section{NDGA attenuates airway hyperresponsiveness and airway inflammation in an experimental asthma model}

As it has been well established that, in cases of allergic inflammation, the oxidative stress-induced production of ROS promotes the activities of proinflammatory redox-sensitive nuclear factors, including NF-кB (Rahman et al., 1999; Dworski et al., 2000; Rahman et al., 2000; Kirkham et al., 2006) and leukotriene release into the airspace as a result of the 5-LOX-mediated arachidonic acid pathway contributes to the release of airway mucus and the infiltration of inflammatory cells, therapy with both antioxidants and the inhibition of 5-LOX activity may have potential advantages. We recently reported that $\alpha$-lipoic acid, a naturally-occurring antioxidant, may exert suppressive effects on allergic airway inflammation and AHR in an experimental asthma model (Cho et al., 2004). Therefore, we attempted to determine whether the administration of NDGA is capable of suppressing the development of the bronchial asthma. To that end, we generated a mouse model of ovalbumin (OVA)-induced asthma, as is depicted in Figure 4A. On days 21, 22, and 23, different NDGA concentrations were either intraperitoneally or intravenously administered. NDGA treatment markedly attenuated OVA-induced hyper-responsiveness to methacholine (Figure 4B). Moreover, both intraperitoneal and intravenous NDGA administration profoundly inhibited the infiltration of inflammatory cells such as macrophages, eosinophils, and lymphocytes into the BAL fluid (Figure 4C). In parallel with this result, NDGA treatment prevented lung inflammation, as was shown by the observed reduction of eosinophil-rich leukocyte infiltration in the peribronchiolar regions, whereas typical pathologic features of asthmatic inflammation were observed in OVA-challenged mice not treated with NDGA (Figure 4D). In addition, enzyme immunoassays revealed that the level of OVA-specific IgE was decreased markedly in NDGA-treated mice as compared with the untreated mice (Figure 4E).

\section{NDGA inhibits the production of Th2 cytokines and proinflammatory cytokine TNF- $\alpha$}

Considering the essential role of Th2 cytokines and TNF- $\alpha$ with regard to the elicitation of allergic inflammatory responses, we measured the concentrations of IL-4, IL-5, IL-13, and TNF- $\alpha$ in BAL fluid, as well as the cells that produce them in the peripheral system. OVA-challenge elicited substantial increases in the concentration of all four cytokines in the BAL fluid, as well as in the IL-4, IL-5, IL-13, 

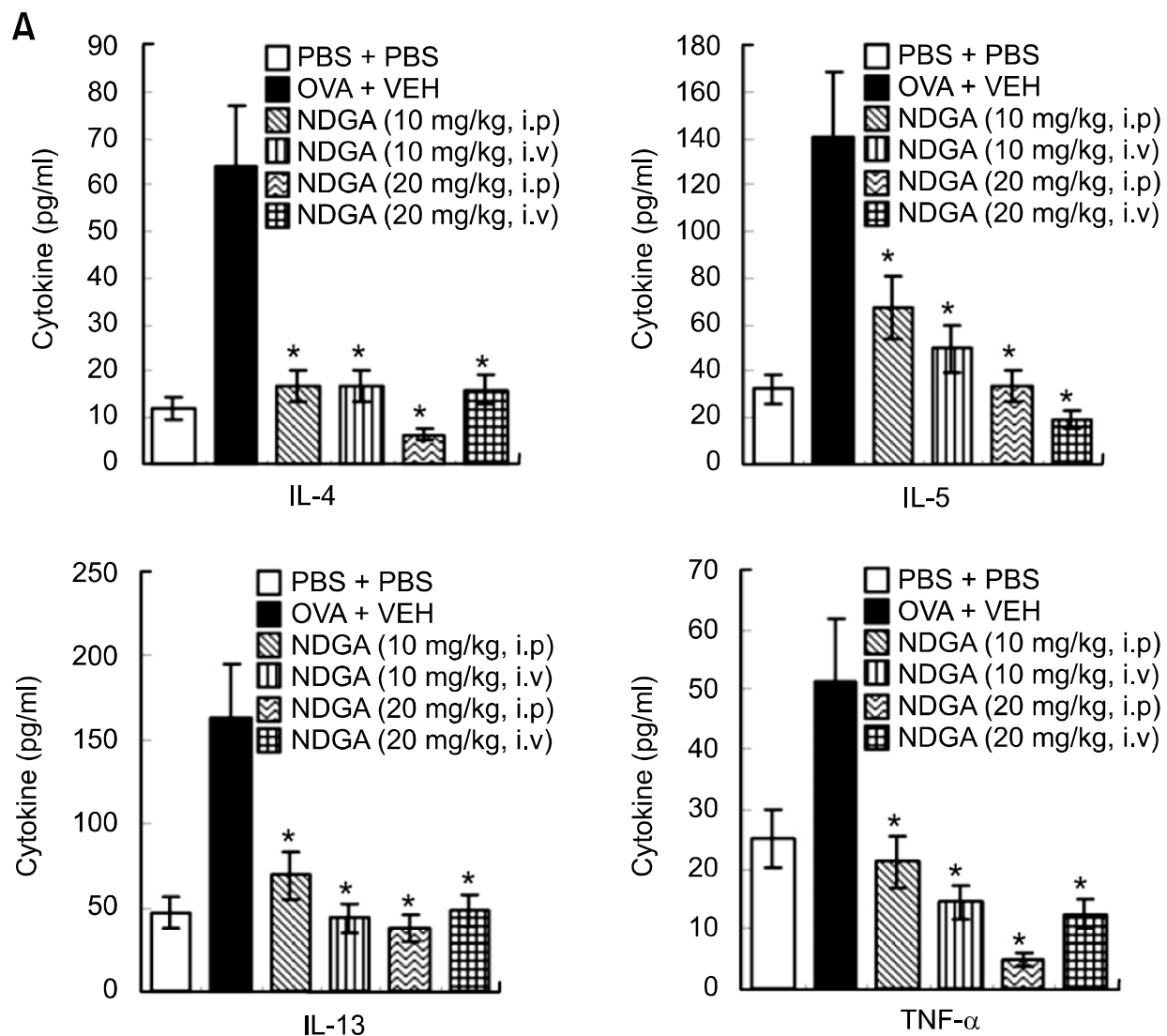

Figure 5. NDGA reduces inflammatory cytokines and the number of cytokine-producing cells. (A) Mouse BAL fluid samples from mice treated as described in the Figure 3 legend were collected $24 \mathrm{~h}$ after the last challenge. Enzyme immunoassays for IL-4, IL-5, IL-13, and TNF- $\alpha$ were conducted as described in the Materials and Methods section. Bars represent mean \pm SE from 6 independent experiments. ${ }^{*} P<0.05$ vs OVA + VEH mice. (B) Mouse splenocytes from mice treated as described in the Figure 3 legend were harvested $24 \mathrm{~h}$ after the last challenge. For the detection of numbers of IL-4, IL-5, IL-13, and TNF- $\alpha$-producing cells, ELISPOT assays were conducted as described in the Materials and Methods section. Spots were counted using Elispot leader 4.0. As a negative control, unstimulated cells were used. No spots were detected in the control wells. Bars represent mean $\pm S E$ from 6 independent experiments. ${ }^{*} P<0.05$ vs OVA + VEH mice.

and TNF- $\alpha$-producing cells in splenocytes (Figure $5 \mathrm{~A}$ and Figure $5 \mathrm{~B}$, closed bars), as compared with the levels and numbers of cells observed after PBS challenge (Figure 5A and B, open bars). The increased levels of these cytokines were markedly reduced by NDGA in a dose-dependent manner, as was the number of the cells that produce them in the splenocytes (Figure $5 \mathrm{~A}$ and $\mathrm{B}$ ).

\section{NDGA inhibits OVA-induced production of TNF- $\alpha$ and the infiltration of macrophages into lung tissue and eosinophils into BAL fluid}

Recent reports have shown that TNF- $\alpha$, along with the Th2 cytokines, may critically contribute to several features of the response, antigen-induced inflammation and AHR, thus promoting allergic responses (Rudmann et al., 2000; Williams et al., 2000; Elias et al., 2003; Akdis et al., 2006; Eder et al., 2006; Umetsu et al., 2006). Furthermore, the release of leukotriene into the airspace as a consequence of the 5-LOX-mediated arachdonic acid pathway contributes to the release of airway mucus and the infiltration of inflammatory cells (Barnes et al., 1998). We finally attempted to determine whether NDGA affects the production of TNF- $\alpha$ to be processed in an allergen-dependent manner. When co-cultured with OVA allergen, a significant upregulation of TNF- $\alpha$ was observed in splenocytes derived from OVA-sensitized and challenged mice, whereas these levels were reduced markedly in NDGA-co-cultured splenocytes derived from OVA-sensitized and challenged mice. This result indicates that NDGA can inhibit the allergeninduced generation of the inflammatory cytokine, TNF- $\alpha$, and thus its effects may contribute, in part, to an amelioration of allergic inflammation, coupled with reductions of Th2 cytokines in vivo, as is shown in Figure 5 (Figure 6A). Intriguingly, when we measured secreted leukotriene $\mathrm{C}_{4}\left(\mathrm{LTC}_{4}\right)$, which 
B
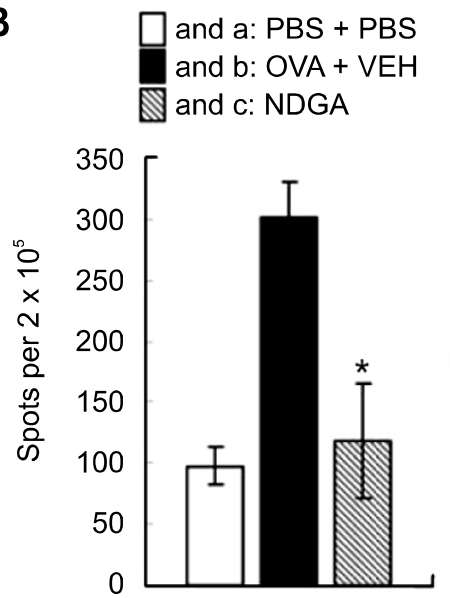

IL-13

and $a: P B S+P B S$

and $b: O V A+V E H$

$\mathbb{N}$ and c: NDGA

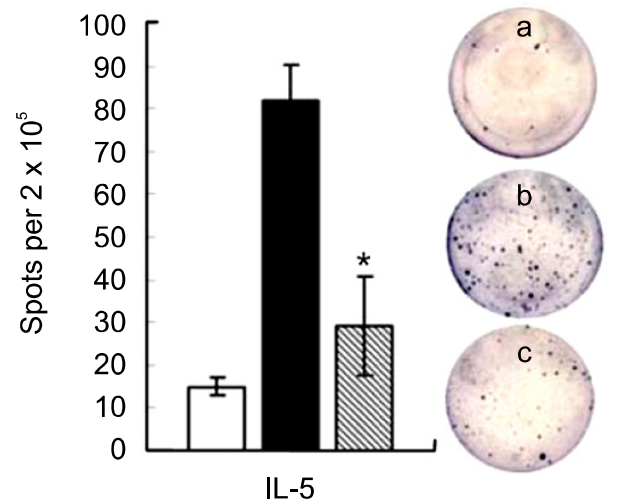

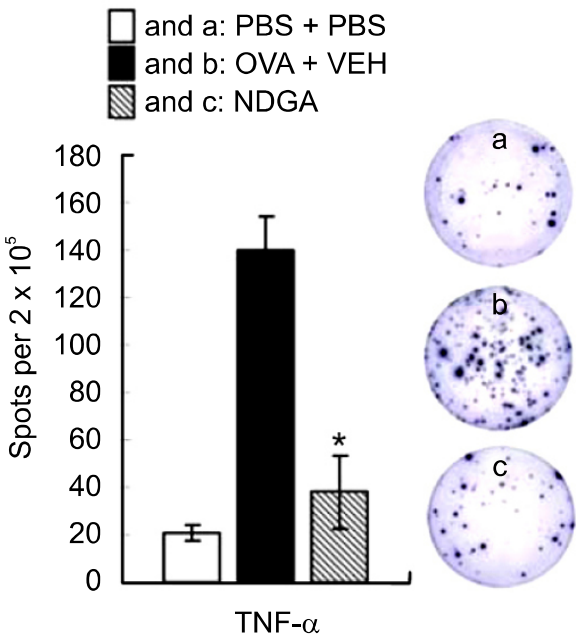

$\square$ and $a: P B S+P B S$

and $b:$ OVA + VEH

and $c:$ NDGA

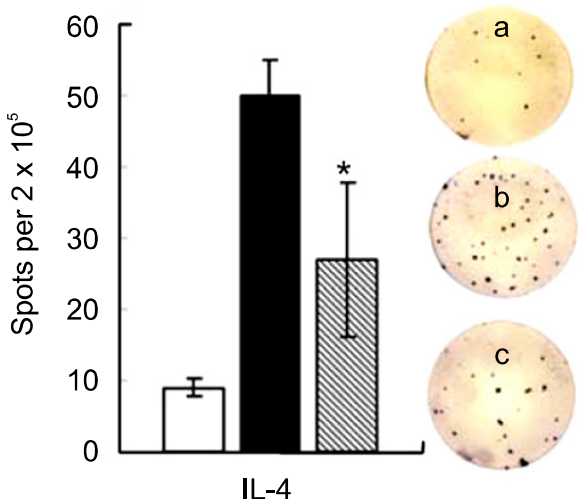

Figure 5. Continued.

is a critical mediator capable of increasing the infiltration of inflammatory cells into the lung, NDGA effected a significant inhibition of $\mathrm{LTC}_{4}$ levels by more than $50 \%$ (Figure $6 \mathrm{~B}$ ). Furthermore, the reduced levels of $\mathrm{LTC}_{4}$ appeared to exert a critical effect on the infiltration of macrophages into the lung. With regard to the relative proportion of macrophages, no significant differences could be detected in the PBS- or OVA-treated mice, whereas in the NDGA-treated mice, significant reductions were detected (Figure 6C). When the absolute numbers of cells were compared, marked increases were detected in the OVA-treated mice, whereas a dramatic reduction was observed in the NDGAtreated mice (Figure 6D). Additionally, the reduction of LTC4 markedly affected the infiltration of eosinophils into BAL fluid as well as macrophages (Figure 6E). These results strongly suggest that NDGA may also function in the arachidonic acid pathway to produce $\mathrm{LTC}_{4}$ as well as the inhibition of pro-inflammatory signaling via the regulation of LOXs, and may result in an attenuation of airway inflammation.

\section{Discussion}

A great deal of emerging evidence suggests that ROS are crucial mediators in intracellular signaling, including the Toll-like receptor signaling pathway, and ROS scavenging or NOX inhibition suppresses LPS-induced cytokine production (Bonizzi et al., 1999; Davies et al., 1999; Lee et al., 1999; Aslan et al., 2003; Tonks et al., 2005; Nakahira et al., 2006; Saito et al., 2006). However, the sources of ROS after the administration of these stimuli remain largely unknown. Primary cellular sources of ROS may be associated with NOX, 5-LOX, and the mitochondria (Babior et al., 1999; Griendling et al., 1999; Kuhn et al., 1999; Van Heerebeek et al., 
2002; Rhee et al., 2003). These ROSs are involved in pro-inflammatory signaling pathway (Babior et al., 1999; Griendling et al., 1999; Van Heerebeek et al., 2002; Ogawa et al., 2003; Genova et al., 2004). The data presented in this study indicate a crucial role for lipooxygenases in pro-inflammatory signaling. NDGA, as LOXs inhibitor, strongly elicited the scavenging activity of intracellular ROS, inhibits TNF- $\alpha$-induced ROS accumulation, and blocks
TNF- $\alpha$-induced NF-kB activation. NDGA has also been consistently shown to inhibit LPS-induced $\mathrm{TNF}-\alpha$ production and NF- $\mathrm{KB}$ activation, thereby indicating that those signalings are critically linked to LOXs activation. The results of previous studies have also shown that IL-1 $\beta$ stimulation resulted in ROS generation via 5-LOX activity (Bonizzi et al. 1999). Those results strongly indicate that 5-LOX activity is required for pro-inflammatory signaling,
A

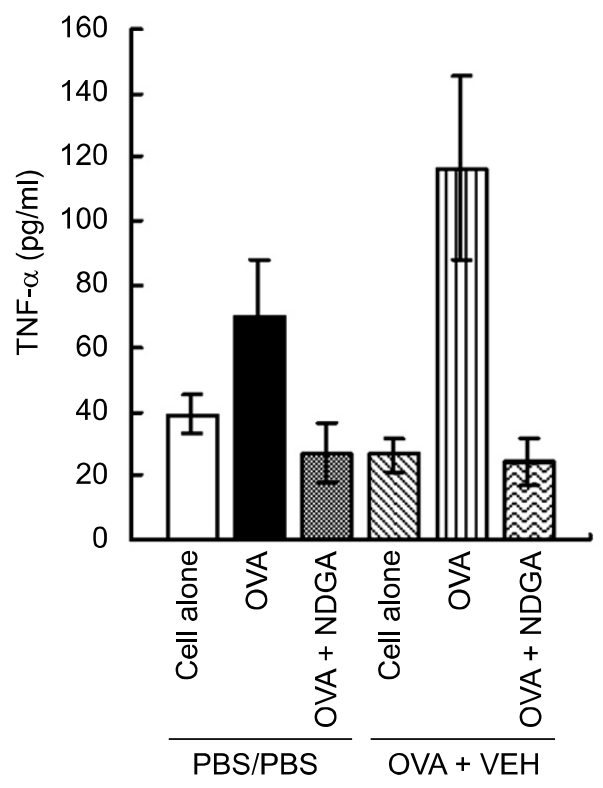

B

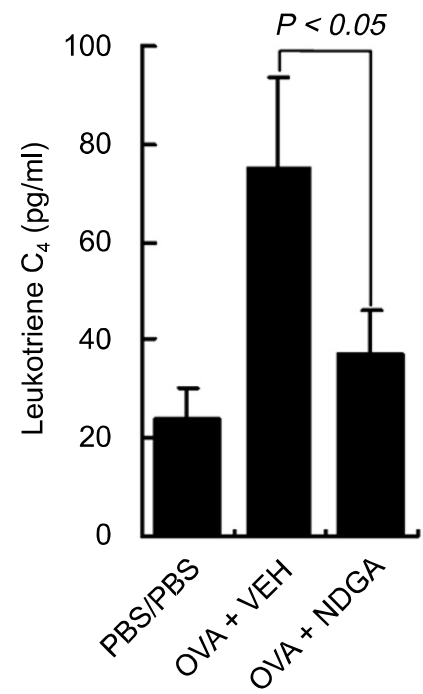

D

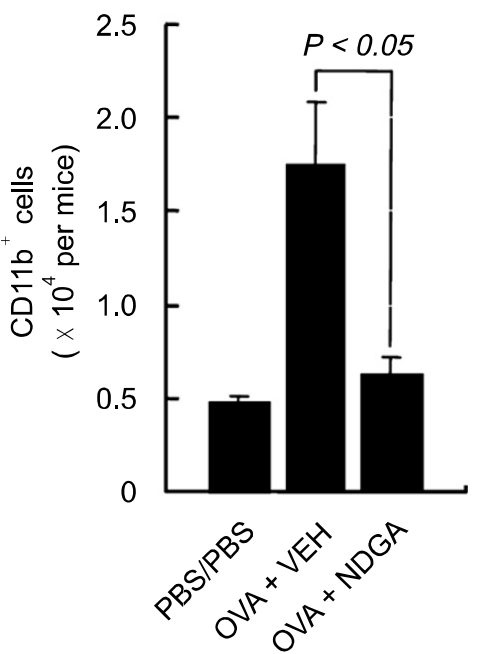

C

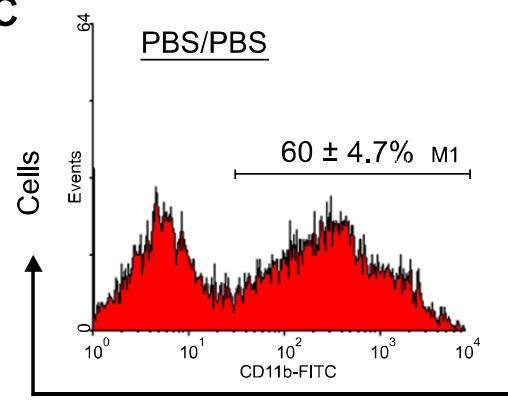

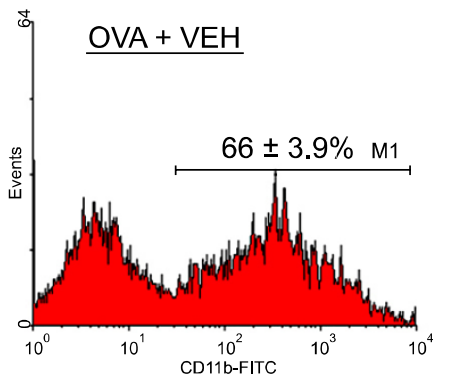

Figure 6. Effects of NDGA on the OVA-specific production of TNF- $\alpha$, infiltration of macrophages into the lung, and leukotriene C4 levels in BAL fluids. (A) Splenocytes were harvested from saline-inhaled mice treated with PBS (PBS + PBS) and OVA-inhaled mice treated with drug vehicle (OVA + VEH). $5 \times$ $10^{5}$ cells per well were plated in 96-well plates, co-cultured with or without $20 \mu \mathrm{g} / \mathrm{ml} \mathrm{OVA}$ for $48 \mathrm{~h}$ in the presence or absence of $5 \mu \mathrm{M}$ NDGA. The quantity of TNF- $\alpha$ in the culture supernatant fractions was measured via ELISA, as described in the Materials and Methods section. Bars represent mean \pm SE from 6 independent experiments. (B) Leukotriene C4 levels in BAL fluids were analyzed via ELISA, as described in the Materials and Methods section. Bars represent mean \pm SE from 6 independent experiments. (C) and (D) Lungs were isolated from saline-inhaled mice treated with PBS (PBS+PBS), OVA-inhaled mice treated with drug vehicle (OVA + VEH), and OVA-inhaled mice intraperitoneally treated with $20 \mathrm{mg} / \mathrm{kg} \mathrm{NDGA}(\mathrm{OVA}+20 \mathrm{mg} / \mathrm{kg}$ i.p). Lung tissue was cut into small fragments, and the infiltrated cells were isolated as described in the Materials and Methods section. After the cells were counted (D), $10^{6}$ per tube were incubated for $40 \mathrm{~min}$ on ice with FITC-conjugated anti-CD11b antibody and analyzed using a FACScalibur apparatus (C). \pm SE indicate standard deviations obtained from 6 different mice. (E) BAL fluids were harvested as described in the Materials and Methods and stained with Diff-Quik solution. The cells were visualized and identified by a microscope. 


\section{E}

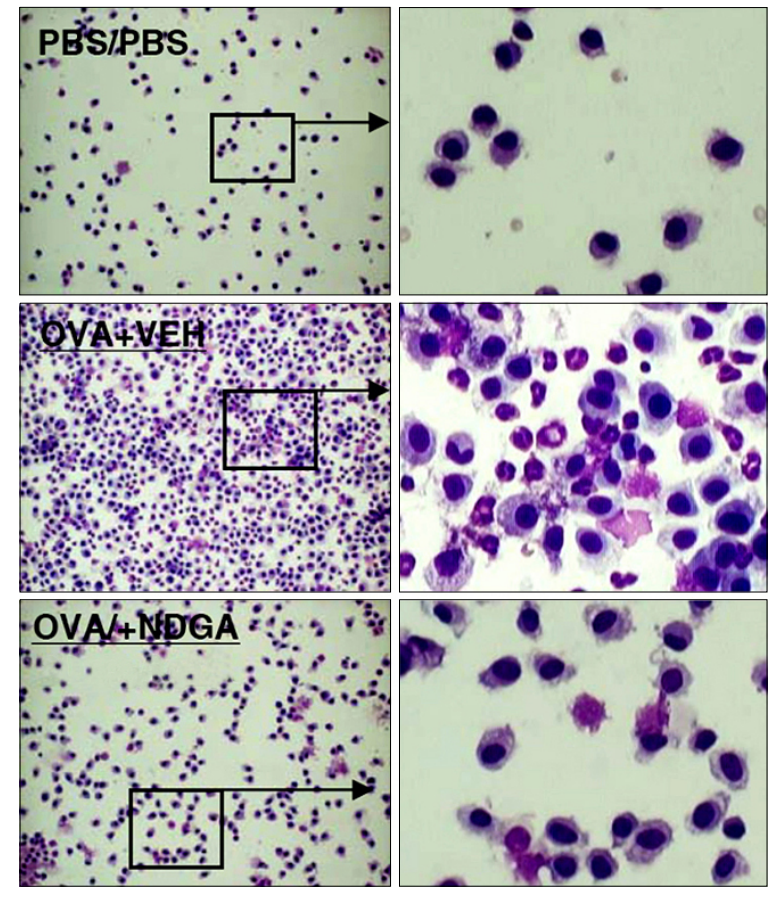

Figure 6. Continued.

such as that associated with $\mathrm{TNF}-\alpha, \mathrm{IL}-1 \beta$, and LPS.

This study, for the first time, evaluated the contribution of LOXs to the pathogenesis of OVA-induced bronchial asthma in mice. The results of numerous studies have revealed that the production of ROS, including superoxide and hydroxyl radicals, hydrogen peroxide, and hypochlorous acid, is augmented, and antioxidant reserves are reduced in asthmatic patients (Rahman et al., 1999; Dworski et al., 2000; Rahman et al., 2000; Kirkham et al., 2006). Moreover, oxidative stress induces an increase in the peroxidation of lipids, proteins, and DNA, as well as the production of chemoattractants, as well as enhancing AHR, airway secretion, and vascular permeability in asthmatic airways (Barnes et al., 1990; Henricks et al., 2001; Andreadis et al., 2003). ROS also promotes the activities of proinflammatory redox-sensitive nuclear factors, including $N F-\kappa B$, thus increasing the allergic inflammation observed in asthmatic patients (Henderson et al., 2002; Rahman et al., 2003). These results show that ROS may perform essential functions for both the induction of airway inflammation and for the pathogenesis of asthmatic diseases. Previous studies have revealed that NDGA exerts pleiotropic effects capable of influencing a wide variety of cellular processes, including TGF- $\beta$-induced signal transduction, leukocyte chemotaxis, myoblast cell differentiation, cancer cell proliferation, and viral proliferation in infected cells (Goetzl et al., 1980; Gnabre et al., 1995; Lee et al., 2003; West et al., 2004; Ito et al., 2005; Youngren et al., 2005; Arasaki et al., 2007). However, its anti-inflammatory effects in allergic inflammation have been investigated to a lesser degree. Our data indicated that treatment with NDGA markedly attenuates the development of airway hyperresponsiveness, OVA-induced bronchiolar inflammation, the infiltration of inflammatory cells into the airway, the release of pro-inflammatory cytokines including Th2, and the number of cytokine-generating cells in the peripheral system in OVA-sensitized and challenged mice.

Several cytokines, including IL-4, IL-5, IL-13, $\mathrm{IL}-1 \beta$, and TNF- $\alpha$, have been detected at elevated levels in the asthmatic lung, and may perform critical functions in the development and maintenance of asthmatic inflammation (Williams et al., 2000; Elias et al., 2003). IL-4, IL-5, and IL-13 regulate allergic inflammation via the promotion of Th2 cell differentiation, eosinophilic inflammation, and $B$ cell differentiation, respectively. A number of studies have previously suggested a role for TNF- $\alpha$ in the development of AHR (Gosset et al., 1991, 1992; Williams et al., 2000; Coward et al., 2002; Aggarwal et al., 2003). In murine asthma models, a deficiency in TNF- $\alpha$ receptors has been determined to result in a marked attenuation of antigeninduced airway inflammation and AHR (Rudmann et al., 2000). Additionally, recent studies have 
shown that anti-TNF- $\alpha$ treatment administered to asthma patients resulted in a marked improvement in asthma symptoms, lung function, and AHR. The most striking of these improvements was that of AHR (Howarth et al., 2005), which further points to the pivotal function of TNF- $\alpha$ in the development of AHR. Additionally, several studies have demonstrated that macrophage migration inhibitory factor (MIF), which is known to be elevated in asthmatic patients and also is known to play a critical function in the pathogenesis of asthma, is a pleiotropic molecule. MIF evidences several pro-inflammatory functions, including the induction of $T N F-\alpha$, the release of IL-1 and NO from the macrophages, and the generation of arachidonic acid and eicosanoids via the induction of phospholipase A2 and cyclooxygenase (Bernhagen et al., 1994; Mitchell et al., 1999). The release of leukotriene into the airspace in response to allergens also critically contributes to the release of airway mucus and infiltration by inflammatory cells (Lewis et al., 1990; Harrison et al., 1995). Our in vivo data show that treatment with NDGA results in a marked reduction in the levels of pro-inflammatory cytokines, and suppresses the infiltration of inflammatory cells into the airway. A possible cellular mechanism by which NDGA may act on these responses involves the activity of LOXs. The $\mathrm{LTC}_{4}$ levels in BAL fluid detected $24 \mathrm{~h}$ after the last challenge were 3 -fold higher in the OVA-sensitized and challenged mice than in the mice receiving $P B S$ alone. Moreover, infiltrations of inflammatory cells into BAL fluid and lung tissue, in addition to the levels of pro-inflammatory cytokines, were determined to have been markedly increased in the OVA-sensitized and challenged mice. These results show that the release of $\mathrm{LTC}_{4}$ may induce the recruitment or migration of inflammatory cells into the lung, and then the secretion of pro-inflammatory cytokines, including Th2 and TNF- $\alpha$. Intriguingly, treatment with NDGA resulted in a significant inhibition of LTC4 levels, pro-inflammatory cytokine levels, and the infiltration of inflammatory cells in OVA-sensitized and challenged mice. This result indicates the essential role of LOXs during airway inflammation. In addition, NDGA also inhibited OVA-induced TNF- $\alpha$ secretion in the peripheral system. Although other functions of LOXs in airway inflammation cannot yet be ruled out, the inhibitory effects of NDGA as a antioxidant in vitro via the regulation of ROS, as well as its effects as an anti-inflammatory agent in vivo may contribute to either direct or indirect effects on the in vivo attenuation of airway inflammation.

In conclusion, our data show the pivotal role of LOXs in pro-inflammatory signaling via intracellular ROS regulation, which may be critical for the activation of $N F-\kappa B$ by that signaling, and the important role of LOXs in the pathogenesis of allergic inflammation.

\section{Acknowledgments}

This work was supported by grants from the Korea Health 21 R\&D Project, the Ministry of Health and Welfare, Republic of Korea (A060009 and A030001).

\section{References}

Adler V, Yin Z, Tew KD, Ronai Z. Role of redox potential and reactive oxygen species in stress signalling. Oncogene 1999;18:6104-11

Aggarwal BB. Signalling pathways of the TNF superfamily: a double-edged sword. Nat Rev Immunol 2003;3:745-56

Akdis CA. Allergy and hypersensitivity: mechanisms of allergic disease. Curr Opin Immunol 2006;18:718-26

Andreadis AA, Hazen SL, Comhair SA, Erzurum SC. Oxidative and nitrosative events in asthma. Free Radic Biol Med 2003;35:213-25

Arasaki K, Tani K, Yoshimori T, Stephens DJ, Tagaya M. Nordihydroguaiaretic Acid affects multiple Dynein-dynactin functions in interphase and mitotic cells. Mol Pharmacol 2007;71:454-60

Aslan M, Ozben T. Oxidants in receptor tyrosine kinase signal transduction pathways. Antioxid Redox Signal 2003;5:781-8

Babior BM. NADPH oxidase: an update. Blood 1999;93: 1464-76

Barnes PJ. Reactive oxygen species and airway inflammation. Free. Radic Biol Med 1990;9:235-43

Barnes PJ, Chung KF, Page CP. Inflammatory mediators of asthma: an update. Pharmacol Rev 1998;50:515-96

Bernhagen J, Mitchell RA, Calandra T, Voelter W, Cerami A, Bucala R. Purification, bioactivity, and secondary structure analysis of mouse and human macrophage migration inhibitory factor (MIF). Biochemistry 1994;33:14144-55

Bonizzi G., Piette J, Schoonbroodt S, Greimers R, Havard L, Merville MP, Bours V. Reactive oxygen intermediatedependent NF-KB activation by interleukin-1 beta requires 5 -lipoxygenase or NADPH oxidase activity. Mol Cell Biol 1999;19:1950-60

Chang TS, Cho CS, Park S, Yu S, Kang SW, Rhee SG. Peroxiredoxin III, a mitochondrion-specific peroxidase, regulates apoptotic signaling by mitochondria. J Biol Chem 2004;279:41975-84

Cho YS, Lee J, Lee TH, Lee EY, Lee KU, Park JY, Moon HB. $\alpha$-Lipoic acid inhibits airway inflammation and hyperresponsiveness in a mouse model of asthma. J Allergy Clin Immunol 2004;114:429-35

Coward WR, Okayama Y, Sagara H, Wilson SJ, Holgate ST, Church MK. NF-KB and TNF- $\alpha$ : a positive autocrine loop in 
human lung mast cells? J Immunol 2002;169:5287-93

Davies KJ. The broad spectrum of responses to oxidants in proliferating cells: A new paradigm for oxidative stress, IUBMB Life 1999;48:41-7

Dworski R. Oxidant stress in asthma. Thorax 2000;55:S51-3

Eder W, Ege MJ, von Mutius E. The asthma epidemic. N Engl J Med 2006;355:2226-35

Elias JA, Lee CG, Zheng T, Ma B, Homer RJ, Zhu Z. New insights into the pathogenesis of asthma. J Clin Invest 2003;111:291-7

Gaddi A, Cicero AF, Pedro EJ. Clinical perspectives of anti-inflammatory therapy in the elderly: the lipoxigenase (LOX)/cycloxigenase (COX) inhibition concept. Arch Gerontol Geriatr 2004;38:201-12

Genova ML, Pich MM, Bernacchia A, Bianchi C, Biondi A, Bovina C, Falasca Al, Formiggini G, Castelli GP, Lenaz G. The mitochondrial production of reactive oxygen species in relation to aging and pathology. Ann NY Acad Sci 2004;1011:86-100

Gnabre JN, Brady JN, Clanton DJ, Ito Y, Dittmer J, Bates RB, Huang RC. Inhibition of human immunodeficiency virus type 1 transcription and replication by DNA sequence-selective plant lignans. Proc Natl Acad Sci USA 1995;92:11239-43

Goetzl EJ. A role for endogenous mono-hydroxy-eicosatetraenoic acids (HETEs) in the regulation of human neutrophil migration. Immunology 1980;40:709-19

Gosset P, Tsicopoulos A, Wallaert B, Vannimenus C, Joseph $M$, Tonnel $A B$, Capron $A$. Increased secretion of tumor necrosis factor $\alpha$ and interleukin- 6 by alveolar macrophages consecutive to the development of the late asthmatic reaction. J Allergy Clin Immunol 1991;88:561-71

Gosset P, Tsicopoulos A, Wallaert B. Tumor necrosis factor $\alpha$ and interleukin- 6 production by human mononuclear phagocytes from allergic asthmatics after lgE-dependent stimulation. Am Rev Respir Dis 1992;146:768-74

Griendling KK, Harrison DG. Dual role of reactive oxygen species in vascular growth. Circ Res 1999;85:562-3

Haddad JJ. Antioxidant and prooxidant mechanisms in the regulation of redox $(\mathrm{y})$-sensitive transcription factors. Cell Signal 2002;14:879-97

Harrison KA, Murphy RC. Isoleukotrienes are biologically active free radical products of lipid peroxidation. J Biol Chem 1995;270:17273-8

Healy AM, Peters-Golden M, Yao JP, Brock TG. Identification of a bipartite nuclear localization sequence necessary for nuclear import of 5-lipoxygenase. J Biol Chem 1999;274: 29812-18

Henderson WR, Chi EY, Teo JL, Nguyen C, Kahn M. A small molecule inhibitor of redox-regulated NF-kappa B and activator protein-1 transcription blocks allergic airway inflammation in a mouse asthma model. J Immunol 2002;169:5294-9

Henricks PA, Nijkamp FP. Reactive Oxygen Species as Mediators in Asthma. Pulm Pharmacol Ther 2001;14:409-20
Howarth PH, Babu KS, Arshad HS, Lau L, Buckley M, McConnel W, Beckett P, Ali M, Cahuhan A, Wilson SJ, Reynolds A, Davies DE, Holgate ST. Tumour necrosis factor $(\mathrm{TNF}-\alpha)$ as a novel therapeutic target in symptomatic corticosteroid dependent asthma. Thorax 2005;60:1012-8

Huang JK, Chen WC, Huang CJ, Hsu SS, Chen JS, Cheng $\mathrm{HH}$, Chang HT, Jiann BP, Jan CR. Nordihydroguaiaretic acid-induced $\mathrm{Ca}^{2+}$ handling and cytotoxicity in human prostate cancer cells. Life Sci 2004;5:2341-51

Ito $\mathrm{H}$, Ueda H, Iwamoto I, Inaguma Y, Takizawa T, Asano T, Kato K. Nordihydroguaiaretic acid (NDGA) blocks the differentiation of C2C12 myoblast cells. J Cell Physiol 2005;202:874-9

Kirkham P, Rahman I. Oxidative stress in asthma and COPD: antioxidants as a therapeutic strategy. Pharmacol Ther 2006;111:476-94

Kuhn $\mathrm{H}$, Thiele BJ. The diversity of the lipoxygenase family. Many sequence data but little information on biological significance. FEBS Lett 1999;449:7-11

Lee $\mathrm{CH}$, Jang YS, Her SJ, Moon YM, Baek SJ, Eling T. Nordihydroguaiaretic acid, an antioxidant, inhibits transforming growth factor-beta activity through the inhibition of Smad signaling pathway. Exp Cell Res 2003;289:335-41

Lee KS, Park HS, Park SJ, Kim SR, Min KH, Jin SM, Li L, Lee YC. An antioxidant modulates expression of receptor activator of NF-кB in asthma. Exp Mol Med 2006;38:217-29

Lee KS, Kim SR, Park HS, Park SJ, Min KH, Lee KY, Choe YH, Hong SH, Han HJ, Lee YR, Kim JS, Atlas D, Lee YC. A novel thiol compound, $\mathrm{N}$-acetylcysteine amide, attenuates allergic airway disease by regulating activation of NF- $\mathrm{KB}$ and hypoxia-inducible factor-1 $\alpha$. Exp Mol Med 2007;39:756-68

Lee SK, Felts A, Parry GC, Armacost LM, Cobb RR. Inhibition of 5 -lipoxygenase blocks IL-1 $\beta$-induced vascular adhesion molecule-1 gene expression in human endothelial cells. $J$ Immunol 1997;158:3401-7

Lee YJ, Shacter E. Oxidative stress inhibits apoptosis in human lymphoma cells. J Biol Chem 1999;274:19792-8

Leone S, Ottani A, Bertolini A. Dual acting anti-inflammatory drugs. Curr Top Med Chem 2007;7:265-75

Lewis RA, Austen KF, Soberman RJ. Leukotrienes and other products of the 5-lipoxygenase pathway. N Engl J Med 1990;323:645-55

Los M, Schenk H, Hexel K, Baeuerle PA, Dröge W, Schulze-Osthoff K. IL-2 gene expression and NF-KB activation through $\mathrm{CD} 28$ requires reactive oxygen production by 5-lipoxygenase. EMBO J 1995;14:3731-40

Miller AA, Drummond GR, Sobey CG. Reactive oxygen species in the cerebral circulation: are they all bad? Antioxid Redox Signal 2006;8:1113-20

Mitchell RA, Metz CN, Peng T, Bucala R. Sustained mitogen-activated protein kinase (MAPK) and cytoplasmic phopholipase A2 activation by macrophage migration inhibitory factor (MIF). J Biol Chem 1999;274:18100-6

Moss MA, Varvel NH, Nichols MR, Reed DK, Rosenberry TL. 
Nordihydroguaiaretic acid does not disaggregate $\beta$ amyloid (1-40) protofibrils but does inhibit growth arising from direct protofibril association. Mol Pharmcol 2004;66: 592-600

Nakahira K, Kim HP, Geng XH, Nakao A, Wang X, Murase N, Drain PF, Wang X, Sasidhar M, Nabel EG, Takahashi T, Lukacs NW, Ryter SW, Morita K, Choi AM. Carbon monoxide differentially inhibits TLR signaling pathways by regulating ROS-induced trafficking of TLRs to lipid rafts. J Exp Med 2006;203:2377-89

O'Byrne PM. Leukotrienes in the pathogenesis of asthma. Chest 1997;111:27S-34S

Ogawa Y, Kobayashi T, Nishioka A, Kariya S, Hamasato S, Seguchi $\mathrm{H}$, Yoshida S. Radiation-induced oxidative DNA damage, 8-oxoguanine, in human peripheral T cells. Int J Mol Med 2003;11:27-32

Rahman I, MacNee W. Lung glutathione and oxidative stress: implications in cigarette smoke-induced airway disease. Am J Physiol 1999;277:L1067-88

Rahman I, MacNee W. Oxidative stress and regulation of glutathione in lung inflammation. Eur Respir J 2000;16: 534-54

Rahman I. Oxidative stress, chromatin remodeling and gene transcription in inflammation and chronic lung diseases. J Biochem Mol Biol 2003;36:95-109

Ramasamy S, Drummond GR, Ahn J, Storek M, Pohl J, Parthasarathy S, Harrison DG. Modulation of expression of endothelial nitric oxide synthase by nordihydroguaiaretic acid, a phenolic antioxidant in cultured endothelial cells. Mol Pharmacol 1999;56:116-23

Rhee SG, Chang TS, Bae YS, Lee SR, Kang SW. Cellular regulation by hydrogen peroxide. J Am Soc Nephrol 2003;14:S211-5
Rudmann DG, Moore MW, Tepper JS, Aldrich MC, Pfeiffer JW, Hogenesch H, Tumas DB. Modulation of allergic inflammation in mice deficient in TNF receptors. Am J Physiol Lung Cell Mol Physiol 2000;279:L1047-57

Saito Y, Nishio K, Ogawa Y, Kimata J, Kinumi T, Yoshida Y, Noguchi N, Niki E. Turning point in apoptosis/necrosis induced by hydrogen peroxide. Free Radic Res 2006; 40:619-30

Samuelsson B. Leukotrienes: mediators of immediate hypersensitivity reactions and inflammation. Science 1983;220:568-75

Tonks NK. 2005. Redox redux: revisiting PTPs and the control of cell signalling. Cell 2005; 121:667-70

Umetsu DT, Dekruyff RH. Immune dysregulation in asthma. Curr Opin Immunol 2006;18:727-32

Van Heerebeek L, Meischl C, Stooker W, Meijer CJ, Niessen HW, Roos D. NADPH oxidase(s): new source(s) of reactive oxygen species in the vascular system? J Clin Pathol 2002;55:561-8

West M, Mhatre M, Ceballos A, Floyd RA, Grammas P, Gabbita SP, Hamdheydari L, Mai T, Mou S, Pye QN, Stewart C, West S, Williamson KS, Zemlan F, Hensley K. The arachidonic acid 5-lipoxygenase inhibitor nordihydroguaiaretic acid inhibits tumor necrosis factor alpha activation of microglia and extends survival of G93A-SOD1 transgenic mice. J Neurochem 2004;91:133-43

Williams CM, Galli SJ. Mast cells can amplify airway reactivity and features of chronic inflammation in an asthma model in mice. J Exp Med 2000;192:455-62

Youngren JF, Gable K, Penaranda C, Maddux BA, Zavodovskaya M, Lobo M, Campbell M, Kerner J, Goldfine ID. Nordihydroguaiaretic acid (NDGA) inhibits the IGF-1 and c-erbB2/HER2/neu receptors and suppresses growth in breast cancer cells. Breast Cancer Res Treat 2005;94:37-46 